Original Paper http://ajol.info/index.php/ijbcs http://indexmedicus.afro.who.int

\title{
Pathogenicity study of some seed-borne fungi of onion (Allium cepa L.) from Burkina Faso
}

\author{
Tobdem Gaston DABIRE ${ }^{*}$, Bawomon Fidèle NEYA ${ }^{1}$, Irénée SOMDA ${ }^{1}$ and \\ Anne LEGREVE ${ }^{2}$ \\ ${ }^{1}$ Université Nazi Boni / Centre Universitaire de Gaoua, 01, P.O. Box 1091, Bobo-Dioulasso 01, Burkina Faso. \\ ${ }^{2}$ Université Catholique de Louvain/ Earth and Life Institute, Croix du Sud 2 box L7.05.03, 1348 Louvain-la- \\ Neuve, Belgium. \\ ${ }^{*}$ Corresponding author; E-mail: drdabiretoo@gmail.com, Phone. (00226) 78271200 / 63760099
}

\section{ACKNOWLEDGMENTS}

The authors are grateful to the ARES-Programme PRD in Belgium for financial support.

\begin{tabular}{lll}
\hline Received: 30-01-2021 & Accepted: 22-06-2021 & Published: 30-06-2021 \\
\hline
\end{tabular}

\begin{abstract}
Onion production in Burkina Faso faces to several constraints including diseases. Symptoms such as seedling damping-off are currently been observed. Most of the fungi responsible for onion diseases are seedtransmitted but in Burkina Faso, little information on onion seed quality were available. In a previous study, Aspergillus niger, Fusarium oxysporum and Fusarium solani were found to be the main fungi present on onion seeds but their responsibility in the development of seedlings damping-off has not been established. The overall aim of this study is to evaluate in vitro, the effect of these fungi on onion seed germination and coleoptile growth in order to establish this responsibility. Onion seeds were inoculated with mycelium suspension of the fungi concentrated at $13.3 \mathrm{~g} / \mathrm{ml}$ and incubated for 6 days under appropriates conditions. All the tested fungal isolates had an inhibitory effect on onion seed germination at rates ranging from 31 to $60 \%$. The Fusarium species were the most virulent. Coleoptile length was also reduced by the fungi, leading to significant growth time-lag at rates ranging from 34 to $100 \%$. Aspergillus niger was the most virulent. In conclusion, Aspergillus niger, Fusarium oxysporum and Fusarium solani are responsible of seedling damping-off of onion in Burkina Faso.
\end{abstract}

(C) 2021 International Formulae Group. All rights reserved.

Keywords: Fusarium, Aspergillus niger, Coleoptile length, Violet of Galmi, Prema 178,

\section{INTRODUCTION}

The main system for cultivating onions in Burkina Faso is to produce seedlings in the nursery from dry seeds, followed by pricking them out in the field. In such a system, the use of good quality seeds is essential in order to prevent plant diseases appearing in the fields and ensure a good crop (Diop et al., 2019). Seed health constitute an important parameter in the certification process of seed (Lepoivre, 2003). The agricultural value of a seed lot depends largely on the presence or not of pathogenic agents in the lot (Bonzi et al., 2012b; Soura et al., 2020). Seed lots can carry 
many plant pathogenic agents that can directly affect their physical quality (discoloration, deformation, rots) and their agricultural value (seedling damping-off, diseases in fields) (Mathur and Kongsdal, 2003). Many studies have highlighted the central role of plant multiplication materials (seeds, cuttings, grafts) in the prevalence of plant diseases (Mathur and Kongsdal, 2003; Zida et al., 2008; Bonzi et al., 2012a). In addition to these negative effects on the productivity of the plants, the fungi carried and transmitted by the seeds mostly produce some mycotoxins (Ikeagwulonu et al., 2020) which deteriorate the nutritive quality of foods (De Marinis et al., 2019). In Burkina Faso, vegetable seeds in general, and onion seeds in particular, are mainly imported. No information about the level of seed contamination by pathogenic agents is given on the labels or other documents accompanying these imported seeds lots. In addition, the high cost of imported seed lots has led some farmers to produce and market local seeds without adequate training in seed production and seed certification. Locally produced seeds are now being increasingly used because they are cheaper, but in many cases, their germination quality is poor (Tarpaga et al., 2011). One of the major constraints to onion production in Burkina Faso is seed rot and seedling damping-off in nurseries. According to the national statistics in 2010, about $30 \%$ of onion farmers were faced with significant seedling mortality rates in nurseries (Tarpaga, 2012). Now, seedling damping-off or seed rot is observed everywhere and then has become an urgent problem to be solved. In order to learn more about the origin of seed rot, seedling damping-off and other diseases occurring in the field, an analysis of the mycoflora in onion seeds used in Burkina Faso was conducted. The results showed that fungal pathogens in the Aspergillus and Fusarium genera were predominant in both imported and locally produced seeds (Dabiré et al., 2016). Some species, such as Aspergillus niger, Fusarium oxysporum and Fusarium solani, were predominant in seed samples (Dabiré et al.,
2016). These fungal species have been reported to be the cause of onion diseases in many areas, being cited in many publications as the causal agents, for example, of seedling damping-off (Özer and Köycü, 2004; Dumbré et al., 2011; Ruchi, 2012). The presence of these species in onion seeds, however, cannot be the only reason for the seed rot and seedling damping-off observed. It is important to test their capacity to cause seeds rot and/or seedling damping-off in controlled conditions in order to establish scientifically that they are the causal agents of these problems. This test is particularly important because of the close link between the pathogenic capacity of many fungal species and environmental conditions (Pariaud et al., 2009). The overall aim of this study is to evaluate in vitro, the effect of these fungi on onion seed germination and coleoptile growth in order to establish their responsibility in the development of seedling damping-off.

\section{MATERIALS AND METHODS}

\section{Fungal isolates and isolation process}

A total of nine isolates were used for the study, of which three were A. niger isolates, three were $F$. oxysporum isolates and three were $F$. solani isolates. The isolation process took place in 2013 and 2014 in the SY-NAIE laboratory in Bobo-Dioulasso, Burkina Faso from onion seeds and infected organs (Table 1). The naturally infected organs were initially disinfected twice with ethanol for $30 \mathrm{sec}$ and then with hypochlorite of sodium (1\%) for $1 \mathrm{~min}$. After disinfection, the organs were rinsed three times with distilled water and dried in aseptic conditions. After drying, they were transferred to Petri dishes filled with potato dextrose agar medium (PDA) and incubated at $25{ }^{\circ} \mathrm{C}$ under a light-dark cycle $(12 / 12 \mathrm{~h})$ for 7 days. The fungal colonies obtained were purified, identified morphologically and kept in tubes containing PDA and topped with paraffin oil.

\section{Seed samples used}

Two seed samples of two onion varieties were used: Prema 178, originating 
from The Netherlands and currently being introduced into Burkina Faso; and Violet of Galmi, a variety that has been widely grown in the country for a long time. This variety is preferred by farmers because of its long shelf life (Tarpaga, 2012).

\section{Inoculum preparation process}

Mycelia suspensions of the isolates, prepared at a concentration of $13.3 \mathrm{mg} / \mathrm{ml}$, were used as inoculum. The preparation of the mycelia suspensions followed the procedure described by Brennan et al., (2003). Five fragments, each $10 \mathrm{~mm}$ in diameter, were placed in the margins of the fungal colony using appropriate and sterile tools, and then put into an Erlenmeyer flask containing 250 $\mathrm{ml}$ of potato dextrose broth (PDB) (fluid medium). The flask was incubated at $25{ }^{\circ} \mathrm{C}$ under a light-dark cycle $(12 / 12 \mathrm{~h})$ for 7 days under constant agitation. The fungal growth product in the flask was placed in a sterile 50 $\mathrm{ml} \mathrm{Falcon} \mathrm{tube} \mathrm{and} \mathrm{centrifuged} \mathrm{at} \mathrm{4,500} \mathrm{G}$ for $15 \mathrm{~min}$. It was then transferred onto the Whatman paper and slightly pressed in order to remove the fluid medium. Then, $532 \mathrm{mg}$ of the fungal product was weighed in sterile conditions and put into a $50 \mathrm{ml}$ Falcon tube containing $40 \mathrm{ml}$ of sterile water as well as Tween $20(0.2 \%)$ and homogenized in order to obtain the target concentration of 13.3 $\mathrm{mg} / \mathrm{ml}$.

\section{Seed disinfection process}

The onion seeds were soaked in a hypochlorite of sodium (1\%) solution and stirred for 5 min with a glass-rod. They were then rinsed three times under aseptic conditions with sterile water, each rinsing taking $20 \mathrm{~min}$. After rinsing, the seeds were aseptically dried on absorbency paper.

\section{Seed inoculation process}

Eight (8) $\mathrm{ml}$ of the mycelia suspension were poured onto a layer of moistened blotter paper that had been placed in a Petri Dish containing about $17 \mathrm{ml}$ of PDA medium and covered with a second dry blotter paper. Then,
25 disinfected seeds were arranged equidistant from each other in two concentric circles, with one seed at the center of the Petri Dish (15-91) in aseptic conditions. The Petri dishes used as control treatments received $8 \mathrm{ml}$ of PDB as a substitution for the mycelia suspension. The filled Petri dishes were incubated at $25^{\circ} \mathrm{C}$ under $12 \mathrm{~h} / 12 \mathrm{~h}$ of alternating NUV and darkness for 6 days. A total of 10 treatments per seed sample were implemented with the nine isolates and the control in four replicates. The experimental design was a completely randomized block.

\section{Evaluation and statistical analysis}

Six days after incubation, data on the number of germinated seeds and the coleoptile lengths were collected and analyzed. The fact that the seeds used as controls had not germinated completely indicated that there were other factors causing the nongermination of the onion seeds. In order to eliminate these factors in the data, the number of non-germinated seeds linked to the action of the fungal isolates tested was determined by subtracting the mean of the nongerminated seeds in the control treatments from the total number of non-germinated seeds in the Petri dishes of each treatment.

These data allowed the percentage of germination inhibition due to the fungi to be calculated, using this formula:

INHIB fungi $\left._{\text {( }} \%\right)=4 *\left(\right.$ NGNG $_{\text {trait }}$ -

NMGNG $_{\text {tem }}$, Where:

INHIB fungi $_{\text {(\%) }}$ = germination inhibition rate due to pathogen;

NGNG trait number of non-germinated seeds in the treatment;

NMGNG $_{\text {tem }}=$ means of non-germinated seeds in the control treatments.

The means of the germination inhibition rates and those of the coleoptile lengths were compared using the Duncan multiple Range Test at the 5\% level with IBM SPSS 22 software 
Table 1: Characteristics and origins of the tested isolates.

\begin{tabular}{lllllc}
\hline Fungal species & $\begin{array}{l}\text { Isolates } \\
\text { Codes }\end{array}$ & Orgins & Variety & Provenance & $\begin{array}{c}\text { Year of } \\
\text { recovery }\end{array}$ \\
\hline Aspergillus niger & $\mathrm{An}_{87-013}$ & Bulbs & Violet de Galmi & Sourou/Di & 2013 \\
& $\mathrm{An}_{43-014}$ & Seeds & Violet de Galmi & Sourou/Débé & 2014 \\
& $\mathrm{An}_{46-014}$ & Bulbs & Violet de Galmi & Sourou/Di & 2014 \\
\hline Fusarium oxysporum & $\mathrm{Fo}_{20-013}$ & Bulbs & Violet de Galmi & Mogtédo & 2013 \\
& $\mathrm{Fo}_{27-013}$ & Roots & Violet de Galmi & Solenzo & 2013 \\
& $\mathrm{Fo}_{33-013}$ & Seeds & Prema 178 & Korsimoro & 2013 \\
& $\mathrm{Fs}_{18-013}$ & Bulbs & Violet de Galmi & Ouahigouya & 2013 \\
& $\mathrm{Fs}_{45-013}$ & roots & Violet de Galmi & Sourou/Débé & 2013 \\
& $\mathrm{Fs}_{46-013}$ & Basale plate & Violet de Galmi & Goinré & 2013 \\
\hline Fusarium solani & & & & \\
\hline
\end{tabular}

\section{RESULTS}

\section{Effect of fungal isolates on seed} germination

The general appearance of the Petri dishes 6 days after incubation varied, depending on the isolate used. The fungal mycelia completely covered the Petri dish or the blotter paper on which the seeds had been arranged (Figure 1). The inoculation of onion seeds with the fungi significantly reduced $(\mathrm{P}<$ $0,05)$ the number of germinated seeds compared with the non-inoculated seeds for both tested varieties. The number of germinated seeds varied from 0 to 15 among the 25 incubated seeds, depending on variety, fungal species and isolates within a fungal species (Table 2). The percentage of seed germination inhibition varied from 31 to $60 \%$, depending on pathogen, isolate and variety used. In general, the $F$. solani isolates produced the highest percentage of seed germination inhibition in the two tested varieties. Violet of Galmi seemed more able to resist Fusarium attacks than Prema 178, whereas Prema 178 was better at resisting Aspergillus attacks (Table 2). Among the $F$. oxysporum isolates, Fo-27-013 was the most virulent, with germination inhibition reaching $60 \%$ for Prema 178 (no germinated seeds) and $53 \%$ for Violet of Galmi. Among the F. solani isolates, Fs-45-013 was the most virulent, with germination inhibition reaching 49 and $52 \%$ for Prema 178 and Violet of Galmi, respectively.

Among the A. niger isolates, An-43014 was the most virulent in terms of germination inhibition, reaching 44 and 55\% for Prema 178 and Violet of Galmi, respectively (Table 2). For seed germination inhibition overall, $F$. solani was the most virulent isolate $(47.65 \%)$, followed by $F$. oxysporum (44.3\%) and A. niger (42.65\%). The Fusarium genus had a greater impact on seed germination than the Aspergillus genus. Overall, the germinative power of Prema 178 seeds was higher than that of Violet of Galmi. 
Effect of fungal isolates on the coleoptile length

Six days after incubation, the germinated seeds had tortuous coleoptiles with a greenish basis and pointed extremities. Non-inoculated seeds (controls) had longer coleoptiles than inoculated seeds (Figure 2).

Coleoptile length varied from 1 to 11.4 $\mathrm{mm}$. Seeds of Prema 178 had longer coleoptiles than those of Violet de Galmi seeds for all the treatments, except for seeds treated with Fo-27 and Fo-33. The mean coleoptile length of the non-inoculated seeds, considered as the reference, was $8.8 \mathrm{~mm}$ for Violet de Galmi and $11.4 \mathrm{~mm}$ for Prema 178 (Figure 3). In general, all the tested isolates negatively and significantly affected coleoptile length (Figure 3). With the exception of two $F$. oxysporum isolates, Violet de Galmi was more sensitive to the fungal actions than Prema 178. On average, the $A$. niger isolates were more virulent than the isolates of both the Fusarium species (Figure 3).

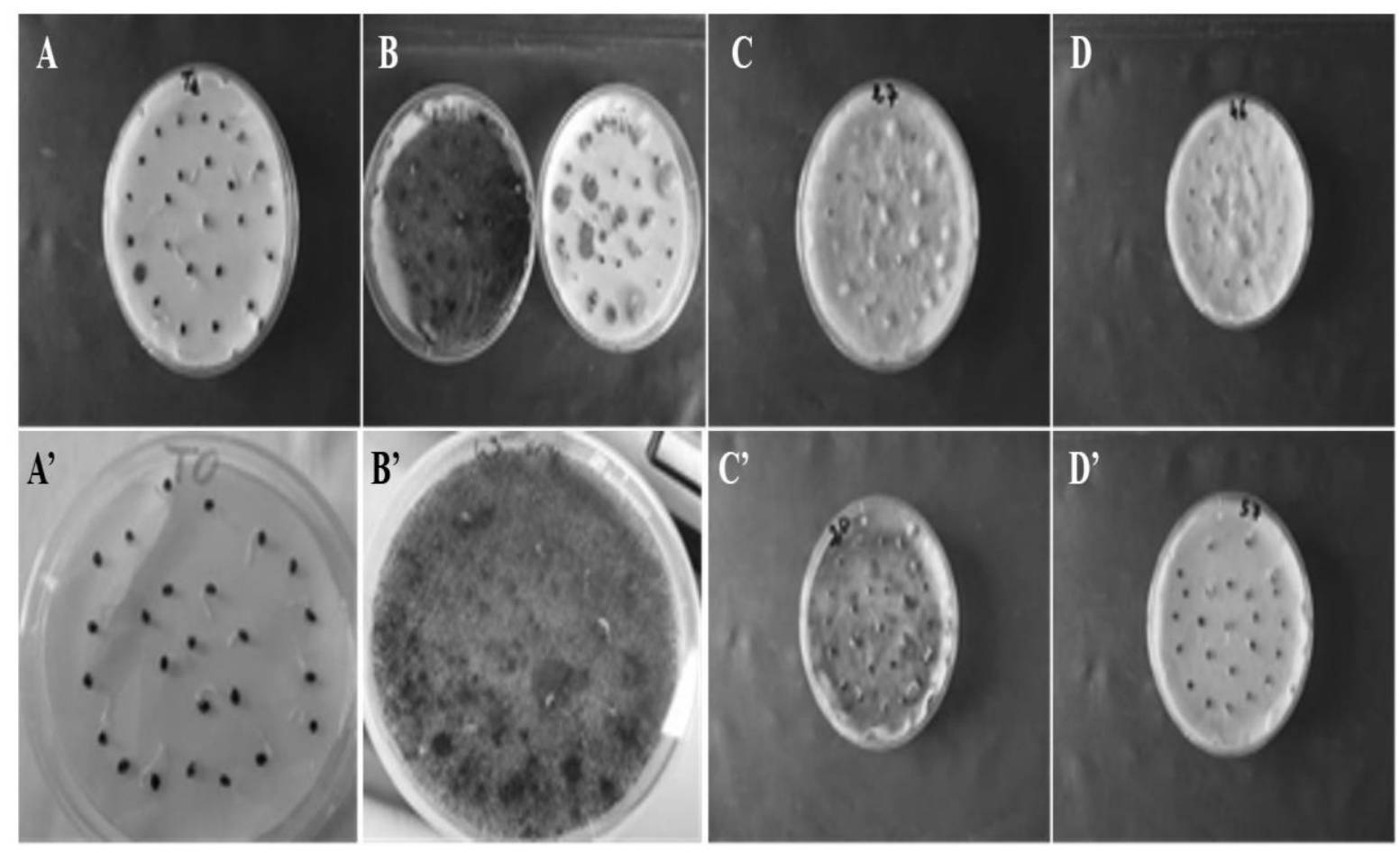

Figure 1: Photographs of seed germination.

AA': Non-inoculated seeds;

BB': Seeds inoculated with A. niger;

CC': Seeds inoculated with $F$. oxysporum;

DD': Seeds inoculated with $F$. solani 
Table 2: Number of germinated seeds and percentage of germination inhibition, according to treatments.

\begin{tabular}{|c|c|c|c|c|c|c|c|c|c|}
\hline \multirow[t]{3}{*}{ Fungal species } & \multirow{3}{*}{$\begin{array}{l}\text { Treatment } \\
\text { codes }\end{array}$} & \multicolumn{8}{|c|}{ Varieties } \\
\hline & & \multicolumn{4}{|c|}{ PREMA 178} & \multicolumn{4}{|c|}{ VIOLET OF GALMI } \\
\hline & & NGS & $\delta$ & PGI & 8 & NGS & $\delta$ & PGI & $\delta$ \\
\hline \multirow[t]{2}{*}{ Controls } & Cont & $15.0^{\mathrm{e}}$ & \pm 0.8 & - & - & $14,5^{\mathrm{c}}$ & \pm 3.1 & - & - \\
\hline & $\mathrm{An}_{43-014}$ & $04.0^{\mathrm{bc}}$ & \pm 1.2 & $44^{\mathrm{bc}}$ & \pm 4.6 & $00.8^{a}$ & \pm 0.5 & $55^{\mathrm{b}}$ & \pm 02.0 \\
\hline \multirow{2}{*}{$\begin{array}{l}\text { Aspergillus } \\
\text { niger }\end{array}$} & $\mathrm{An}_{46-014}$ & $02.0^{\mathrm{ab}}$ & \pm 1.6 & $52^{\mathrm{cd}}$ & \pm 6.5 & $03.0^{\mathrm{ab}}$ & \pm 3.4 & $46^{\mathrm{ab}}$ & \pm 13.5 \\
\hline & $\mathrm{An}_{87-014}$ & $07.3^{d}$ & \pm 1.7 & $31^{\mathrm{a}}$ & \pm 6.8 & $04.5^{\mathrm{ab}}$ & \pm 2.9 & $40^{\mathrm{ab}}$ & \pm 11.6 \\
\hline \multirow{3}{*}{$\begin{array}{l}\text { Fusarium } \\
\text { oxysporum }\end{array}$} & $\mathrm{Fo}_{20-013}$ & $06.8^{\mathrm{cd}}$ & \pm 2.2 & $33^{\mathrm{ab}}$ & \pm 8.9 & $05.5^{\mathrm{b}}$ & \pm 2.6 & $36^{\mathrm{a}}$ & \pm 10.6 \\
\hline & $\mathrm{Fo}_{27-013}$ & $00.0^{\mathrm{a}}$ & \pm 0.0 & $60^{\mathrm{d}}$ & \pm 0.0 & $01.3^{\mathrm{ab}}$ & \pm 1.3 & $53^{\mathrm{b}}$ & \pm 05.0 \\
\hline & $\mathrm{Fo}_{33-013}$ & $04.0^{\mathrm{bc}}$ & \pm 2.6 & $44^{\mathrm{bc}}$ & \pm 10.3 & $04.5^{\mathrm{ab}}$ & \pm 3.7 & $40^{\mathrm{ab}}$ & \pm 14.8 \\
\hline \multirow{3}{*}{$\begin{array}{l}\text { Fusarium } \\
\text { solani }\end{array}$} & $\mathrm{Fs}_{18-013}$ & $04.3^{b c}$ & \pm 2.1 & $43^{\mathrm{bc}}$ & \pm 8.3 & $03.8^{\mathrm{ab}}$ & \pm 4.1 & $43^{a b}$ & \pm 16.5 \\
\hline & $\mathrm{Fs}_{45-013}$ & $02.8^{a b}$ & \pm 2.1 & $49^{\mathrm{cd}}$ & \pm 8.3 & $01.5^{\mathrm{ab}}$ & \pm 1.3 & $52^{a b}$ & \pm 05.2 \\
\hline & $\mathrm{FS}_{46-013}$ & $02.0^{\mathrm{ab}}$ & \pm 2.5 & $52^{\mathrm{cd}}$ & \pm 9.8 & $02.8^{\mathrm{ab}}$ & \pm 1.3 & $47^{a b}$ & \pm 05.0 \\
\hline \multirow{3}{*}{ STAT } & F. values & \multicolumn{2}{|c|}{20.904} & \multicolumn{2}{|c|}{21.327} & \multicolumn{2}{|c|}{8.617} & \multicolumn{2}{|c|}{9.954} \\
\hline & P. values & \multicolumn{2}{|c|}{0.000} & \multicolumn{2}{|c|}{0.000} & \multicolumn{2}{|c|}{0.000} & \multicolumn{2}{|c|}{0.000} \\
\hline & Signif. & \multicolumn{2}{|c|}{ HS } & \multicolumn{2}{|c|}{ HS } & \multicolumn{2}{|c|}{ HS } & \multicolumn{2}{|c|}{ HS } \\
\hline
\end{tabular}

NGS: Number of germinated seeds out of 25

PGI: Percentage of germination inhibition (\%)

Means followed by the same letter within each column are not significantly different at the 0.05 level using the Duncan range test.

HS: Highly significant

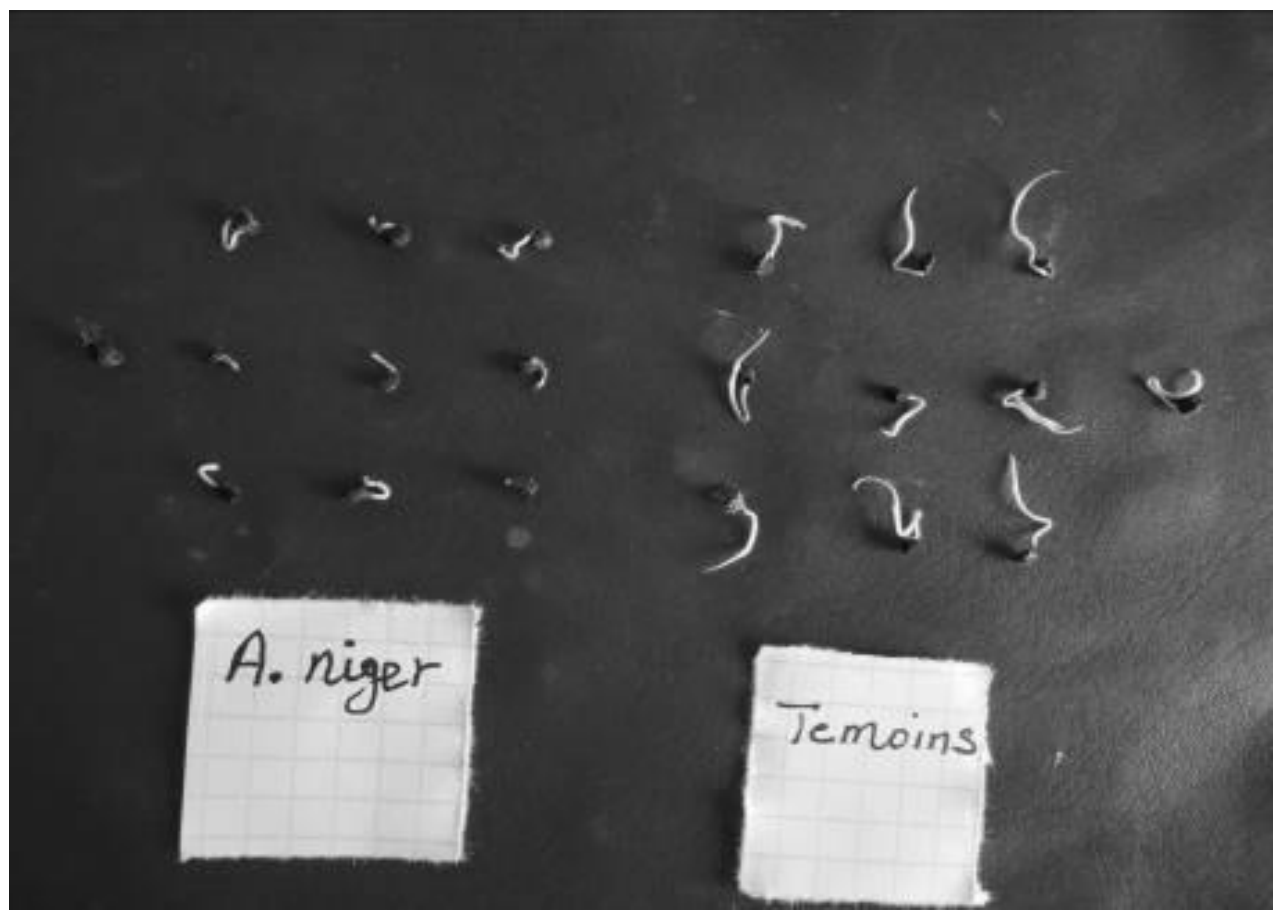

Figure 2: Coleoptiles of seeds inoculated with A. niger and coleoptiles of untreated seeds. 


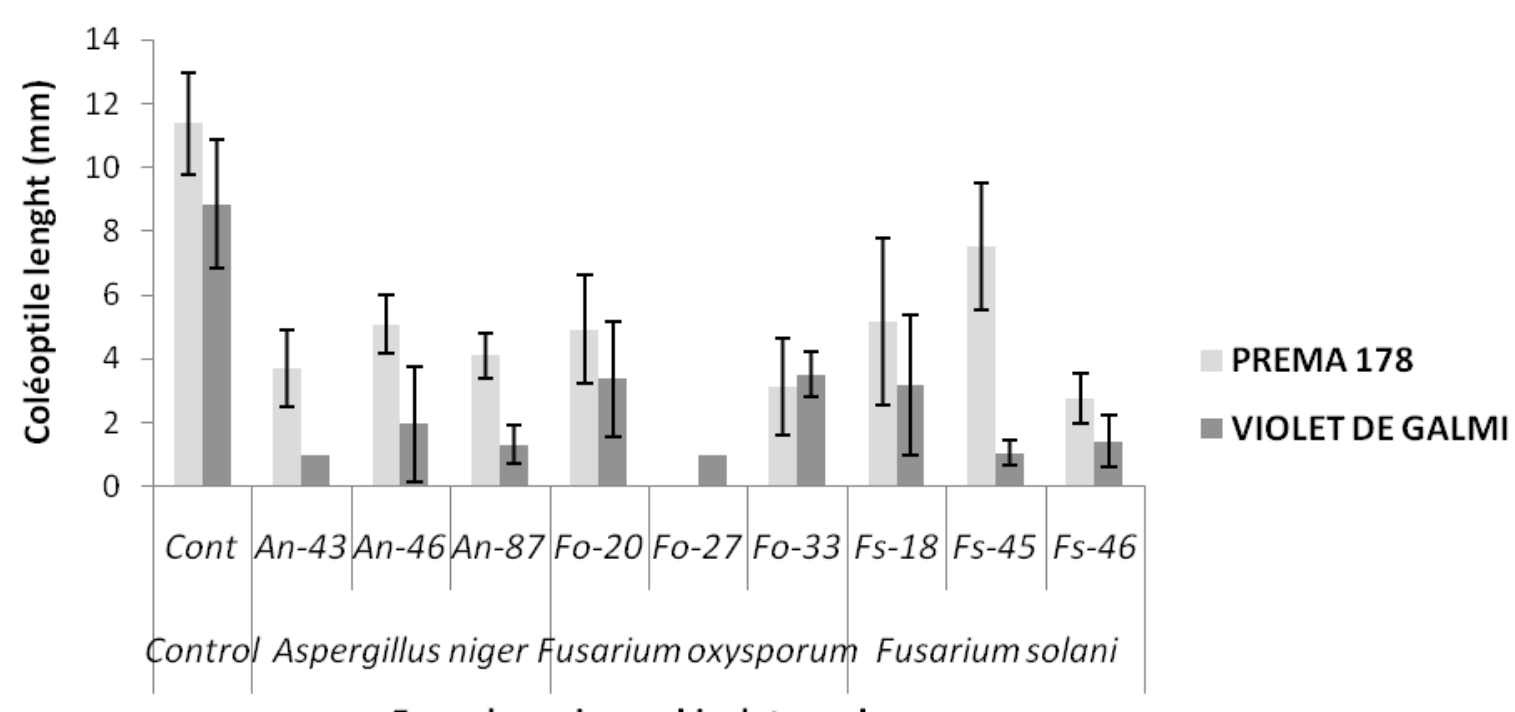

Fungal species and isolate codes

Figure 3: Coleoptile length of onion seeds 6 days after incubation (DAI), according to treatments.

\section{DISCUSSION}

Fusarium oxysporum and Fusarium solani are widely cited as being responsible for basal rot in onion in many production areas (Smolinska and Kowalczyk, 2014; Zlata et al., 2008; Schwartz and Mohan, 2008). Aspergillus niger has been reported as the main causal agent of black mould in onions during bulb storage (Özer and Köycü, 2004). These fungi have also been reported to be responsible for seed rot and seedling damping-off in onion (Özer and Köycü, 2004; Taylor et al., 2013). After an analysis of the mycoflora on onion seeds used in Burkina Faso, performed at the SY-NAIE laboratory at the Polytechnic University of Bobo-Dioulasso in Burkina Faso, these three fungal species were the main ones found in onion seed samples from Burkina Faso (Dabiré et al., 2016) but their responsibility in the development of seedlings damping-off has not been established. The overall aim of this study was to evaluate in vitro, the effect of these fungi on onion seed germination and coleoptile growth in order to establish this responsibility. Seed inoculation with the fungal isolates showed that all the tested isolates negatively affected seed germination and seedling development. Several authors, including Özer and Köycü (2004), Dabiré et al. (2016), have reported that A. niger significantly reduced seed germination and seedling damping-off in onion. Fusarium species are known to cause seed rot damage in tree nurseries (Zehhar et al., 2006). Dissanyake et al. (2009) reported that shallot (Allium fistulosum) seeds, inoculated with isolates of $F$. oxysporum, $F$. solani and $F$. moniliforme, lost their germinative power at rates ranging from 50 to $65 \%$. A similar phenomenon was observed by Djébali et al. (2014) for wheat seeds inoculated with $F$. culmorum. The effect of Fusarium species on seed germination has also been reported by Zehhar et al. (2006). Özer et al. (1999) suggested that seed rot and seedling mortality caused by $A$. niger and $F$. oxysporum could due to the abundant secretion of polygalacturonase induced by the fungi, which led rapidly to seed tissue damage and was the main cause of death. Aspergillus niger was the most frequent species detected in onion seeds. This fungus is ubiquitous in nature and can colonize a wide variety of substrates (Ruchi, 2012). The main source of dissemination of $A$. niger is via contaminated 
seeds. It is a strong fungus and affects onion seeds so extensively that fungicide treatments are seldom efficient against it (Sinclair and Letham, 2001; Özer et al., 2009). In general, Fusarium species are the main cause of seed rot and seedling damping-off in many crops, but often the effects observed are the results of the actions of many fungal species (Schwartz and Mohan, 2008). Fusarium species abound in the soil of vegetable growing areas as chlamydospores (Schwartz and Mohan, 2008) and are the main cause of poor seedling emergence (Özer and Köycü, 2004). Their introduction into production areas is usually via seeds and agricultural tools (Schwartz and Mohan, 2008). Seeds production fields infected by basal rot produce seeds that are highly infected by $F$. oxysporum (Cramer, 2000).

The damage inflicted by $F$. oxysporum on seed germination and coleoptile length differed greatly. This finding accords with those reported by Taylor et al. (2013) who saw the same phenomenon when working with $F$. oxysporum isolates on onion seeds. A wide variation in aggressiveness among isolates of the same Fusarium species on onion seedlings was also observed by Palmero et al. (2012). The differences in aggressiveness among isolates of the same species were due to the use of different pathogenicity genes by each colony during seed attacks (Cuomo et al., 2007). Ramos et al. (2007) and De Vega-Bartol et al. (2011) reported finding a great quantity of a transcription factor called ftf1 (Fusarium transcription factor 1) in the cytoplasm of extremely virulent $F$. oxysporum isolates. This factor seems to play an important role in the initiation and development of infection. The production level of some pectinolytic enzymes (Beugré et al., 2019) (involved in seed infection) could explain the differences in aggressiveness among $F$. oxysporum isolates (Özer et al., 2003). In general, F. solani isolates were more virulent than those of $F$. oxysporum. This difference could be explained by the location of the fungus on onion seed. Mathur and Kongsdal (2003) reported that Fusarium species can infect seeds as spores on the surface or as mycelium inside the seed integument. Their effect on the seeds would then vary, depending on infection mode. Violet of Galmi tended to more sensitive to most of the fungal isolates than Prema 178. Özer et al. (2003) explained that for each variety-isolate interaction involving $F$. oxysporum, for example, the damage intensity depended on the nature and quantity of pectinolytic enzymes produced by the pathogen, on the one hand, and the nature and quantity of antifungal compounds produced by the variety, on the other. An interesting finding in our study was that farmers select Prema 178 (shown by our study to be the less sensitive variety) to produce onions during the rainy season, which is just when all the conditions that favor fungal diseases are present in Burkina Faso. If tolerance of these three fungal species can be achieved, this would enhance the possibility of producing good quality onion crops during the rainy season.

\section{Conclusion}

In conclusion, our study found that $A$. niger, $F$. oxysporum and $F$. solani are pathogenic for onion seeds. They reduced seed germinative power at rates ranging from 31 to $60 \%$ for the Prema 178 variety and from 36 to $52 \%$ for the Violet of Galmi variety. They also significantly reduced coleoptile length, compared with non-inoculated seeds. Fusarium species had a greater effect on seed germination and $A$. niger had a greater effect on coleoptile growth. Prema 178 was found to be more tolerant than Violet of Galmi. Our study showed that seed rot and seedling damping-off in onion production nurseries in Burkina Faso could be due largely to the infection of seeds by Aspergillus and Fusarium species. These results suggest that efficient seed disinfection methods need to be devised and applied by farmers in order to prevent disease problems in onion nurseries, in the field and during bulb storage. 


\section{COMPETING INTERESTS}

The authors declare that they have no competing interests

\section{AUTHORS' CONTRIBUTIONS}

TGD: Study design, conduct of essays, drafting of the manuscript. BFN: Performing statistical analyzes, critical reading of the manuscript. IS: Review of the manuscript. AL: Supervision of manipulations, critical reading of the manuscript.

\section{ACKNOWLEDGMENTS}

This study was carried out at the laboratory of Phytopathology at the Earth and Life Institute in the Faculty of Bio-ingénieurs at the "Université Catholique de Louvain (UCL)" in Belgium. The authors would like to express their gratitude to all the workers in this laboratory for their many contributions.

\section{REFERENCES}

Beugré MM, Konan FKY, Yapo SES, Konan EK, Kouadio JY. 2019. Effet du temps de chauffage des graines de palmier à huile (Elaeis guineensis Jacq.) sur quelques métabolites au cours du processus de la germination. Int. J. Biol. Chem. Sci., 13(7): 3202-3213. DOI: https://dx.doi.org/10.4314/ijbcs.v13i7.19

Bonzi S, Somda I, Zida PE, Sérémé P. 2012a. In vitro antifungal activity of various local plant extracts in the control of Phoma sorghina (Sacc.) Boerema and Colletotrichum graminicola (Ces.) Wilson, as sorghum seed mold pathogen in Burkina Faso. Tropicultura, 30(2): 103-106.

DOI: http://www.tropicultura.org/text/v30n2/1 03

Bonzi S, Somda I, Zida PE, Sereme P. 2012b. Efficacy of plant extract and effect of seed soaking duration on treatment of sorghum seed naturally infected by Colletotrichum graminicola and Phoma sorghina. Archives of Phytopathology and Plant Protection, 45(12): 14051410.

DOI: https://doi.org/10.1080/03235408.2012.6 74713

Brennan MJ, Fagan B, Van Maanen A, Cooke BM, Doohan FM. 2003. Studies on in vitro growth and pathogenicity of European Fusarium fungi. European Journal of Plant Pathology, 109: 577587. DOI: https://doi.org/10.1023/A:102471241532 6

Cramer CS. 2000. Breeding and genetics of Fusarium basal rot resistance in onion. Euphytica, 115: 159-166. DOI: https://doi.org/10.1023/A:100407190764 2

Cuomo CA, Güldener U, Xu J, Trail F, Turgeon BG, Pietro ADi, Ouellet T. 2007. The Fusarium graminearum Genome reveals a link between localized polymorphism and pathogen specialization. Rep. M. Nature, 317(5843): $\quad$ 1400-2. DOI: https://doi.org/10.1126/science.1143708

Dabiré TG, Bonzi S, Somda I and Legrève A. 2016. Identification of seed-borne fungi of onion (Allium cepa L.) in Burkina Faso. International Journal of Innovation and Scientific Research, 25(2): $\quad$ 562-575. DOI: http://www.ijisr.issr-journals.org/

De Marinis P, Spada A, Aristil J. 2019. Evaluation des paramètres productifs et quantification d'aflatoxine de sept variétés de maïs (Zea mays L.) testées en Haïti. Int. J. Biol. Chem. Sci., 13(7): 3009-3022.

DOI: https://dx.doi.org/10.4314/ijbcs.v13i7.3

De Vega-Bartol JJ, Martin-Dominguez R, Ramos B, Garcia-Sanchez MA, DiazMinguez JM. 2011. New virulence groups in Fusarium oxysporum f. sp. phaseoli: the expression of the gene coding for the transcription factor FTF1 correlates with virulence. Phytopathology, 101: 470-9. DOI: https://doi.org/10.1094/PHYTO-09-100252

Desjardins AE, Manandhar G, Plattner RD, Maragos CM, Shrestha K, McCormick 
SP. 2000. Occurrence of Fusarium species and mycotoxins in Nepalese Maize and Wheat and the effect traditional processing method on mycotoxin levels. J. Agric. Food Chem. 48: $1377-1383 . \quad$ DOI: https://doi.org/10.1021/jf991022b

Diop P, Sylla ES, Diatte M, Labou B, Diarra K. 2019. Effect of cut seed tubers and pre-germination on potato tuber yield. Int. J. Biol. Chem. Sci., 13(7): 31573163.

DOI: https://dx.doi.org/10.4314/ijbcs.v13i7.15

Dissanayake CM, Kashima R, Tanaka S, Ito S. 2009. Pathogenic variation and molecular characterization of Fusarium species isolated from wilted Welsh onion in Japan. J. Gen. Plant. Pathol., 75: 3745. DOI: https://doi.org/10.1007/s10327008-0135-z

Djébali N, Tiyab N, Gargouri S, Hessini K. 2014. Effet d'osmo-amorçage des grains sur la germination, la croissance du blé dur à Fusarium culmorum. In: Journée nationale sur la valorisation des résultats de la recherche sur les grandes cultures. Tunis le 17/04/2014. Retrieved from: http://www.iresa.agrinet.tn/images/Djeba li_Naceur.pdf

Dumbré S, Guldekar D, Potdukhe RS. 2011. Survey of seed-borne fungi of onion (Allium cepa L.) from various locations of MAHARASHTRA. Journal of Soils and Crops, 21(2): 221-224. DOI: https://www.cabi.org/isc/FullTextPDF/2 012/20123022545.pdf

Ikeagwulonu RC, Onyenekwe CC, Ukibe NR, IKIM CG, Ehiaghe FA, Emeje IP, Ukibe SN. 2020. Mycotoxin contamination of herbal medications on sale in Ebonyi State, Nigeria. Int. J. Biol. Chem. Sci., 14(2): 613-625, 2020. DOI: https://dx.doi.org/10.4314/ijbcs.v14i2.24

Lepoivre F. 2003. Phytopathologie: Bases moléculaires et biologiques des pathosystèmes et fondements des stratégies de lutte (edition de Boeck Université). Presses Agronomiques de Gembloux : Belgique.
Mathur SB, Kongsdal O. 2003. Common Laboratory Seed Health Testing Methods for Detecting Fungi $\left(1^{\text {st }}\right.$ edn). Kandrups Bogtrkkeri Publication, Denmark.

Özer N, Chilosi G, Magro P. 1999. Polygalacturonase production by Aspergillus niger: Expression in onion seeds and possible involvement in virulence. Journal of Plant Pathology, 81: 17-24. DOI: https://www.jstor.org/stable/41997937

Özer N, Köycü ND, Chilosi G, Pizzuolob PH, Coşkuntunaa A, Magro P. 2003: Pectolyticisoenzymes by Fusarium oxysporum f. sp. cepae and antifungal compounds in onion cultivars as a response to pathogen infection. Canadian Journal of Plant Pathology, 25(3): 249-257. DOI: https://doi.org/10.1080/07060660309507 077

Özer N, Köycü ND. 2004. Seed-borne fungal diseases of onion and their control. In Disease Management of Fruits and Vegetables, Mukerji KG (ed.). Academic Publishers Kluwer: Dordrecht, 281-306.

Özer N, Koç M, Der B. 2009. The sensitivity of Aspergillus niger and Fusarium oxysporum f. sp. Cepae to fungistasis in onion growing soils. Journal of Plant Pathology, 91: 401-410. DOI: https://dx.doi.org/10.4454/jpp.v91i2.970

Pariaud B, Ravigné V, Halkett F, Goyeau H, Carlier J, Lannou C. 2009. Aggressiveness and its role in the adaptation of plant pathogens. Plant Pathology, 58: 409-424. DOI: https://doi.org/10.1111/j.13653059.2009.02039.x

Palmero D, Miguel de Cara, Nosir W, Gálvez L, Cruz A, Woodward S, González-Jaén MT, Tello JC. 2012.Fusarium proliferatum isolated from garlic in Spain: identification,toxigenic potential and pathogenicity on related Allium species. Phytopathologia Mediterranea, 51(1) : 207-218. DOI:10.14601/Phytopathol_Mediterr10341 
Ramos B, Alves-Santos FM, Garcia-Sanchez MA, Martın Rodrigues N, Eslava AP, Diaz-Minguez JM. 2007. The gene coding for a new transcription factor (FTF1) of Fusarium oxysporum is only expressed during infection of common bean. Fungal Genetics and Biology, 44: 864-876.

DOI: https://doi.org/10.1016/j.fgb.2007.03.003

Ruchi S. 2012. Pathogenicity of Aspergillus niger in plants. Cibtech Journal of Microbiology, 1(1): 47-51. DOI: http://www.cibtech.org/cjm.htm

Schwartz HF, Mohan KS. 2008. Basal rot of onion. In Compendium of Onion and Garlic Diseases (2nd edn), Schwartz FH, Mohan Krishna S (eds). APS Press: Minnesota; 12-14.

Sinclair PJ, Letham DB. 2001. Incidence and sites of visible infection of Aspergillus niger on bulbs of two onion (Allium cepa) cultivars. Aust. Plant Pathol., 25: 8-11. DOI: https://doi.org/10.1071/AP96002

Smolinska U, Kowalczyk W. 2014. The impact of the Brassicaceae plant materials added to the soil on the population of Fusarium solani (Mart.) and Fusarium oxysporum Schlecht. Journal of Horticultural Research, 22(1): 123-129. DOI: https://doi.org/10.2478/johr-2014-0015

Soura HB, Gnancadja-André SL, Zandjanakou-Tachin M, Gandonou C, Baba-Moussa FAK. 2020. Etude de l'effet de Cercospora oryzae Miyake sur la qualite des grains du riz et le developpement de la ternissure. Int. J. Biol. Chem. Sci., 14(2): 440-451. DOI: https://dx.doi.org/10.4314/ijbcs.v14i2.11

Tarpaga, VW, Rouamba A, Tamini Z. 2011. Effects of the production season and the size of onion bulbs (Allium cepa L.) on their storage life at room temperature and humidity in Burkina Faso. Agric. Biol. J.N. Am., 2(7): 1072-1078. DOI: 10.5251/abjna.2011.2.7.1072.1078

Tarpaga WV. 2012. Contribution à l'étude de la montaison prématurée des variétés tropicales d'oignon (Allium cepa L.): Cas du Violet de Galmi cultivé au Nord du Burkina Faso. Thèse de Doctorat de l'Université de Ouagadougou, Ouagadougou, Burkina Faso, p.118.

Taylor A, Vagany V, Barbara DJ, Thomas B, Pink DAC, Clarkson JP. 2013. Identification of differential resistance to six Fusarium oxysporum f. sp. cepae isolates in commercial onion cultivars through the development of a rapid seedling assay. Plant Pathology, 62(1): 103-111.

DOI: https://doi.org/10.1111/j.13653059.2012.02624.x

Zehhar G, Ouazzani Touhami A, Badoc A, Douira A. 2006. Effet des Fusarium des eaux de rizière sur la germination et la croissance des plantules de riz. Bull. Soc. Pharm. Bordeaux, 145: 7-18.

Zida PE, Séremé P, Leth V, Sankara P. 2008. Effect of aqueous extracts of Acacia gourmaensis A. Chev and Eclipta alba (L.) Hassk. on seed health, seedling vigour and grain yield of sorghum and pearl millet. Asian Journal of Plant Pathology, 2(1): 40-47. DOI: https://dx.doi.org/10.3923/ajppaj.2008.4 0.47

Zlata D, Jelena T, Stevan N, Jelica M, Mijana A, Svjetlana R. 2008. Fusarium rot of onion and possible use of bioproduct. Proc. Na. Sci., 114: 135-148. DOI: http://dx.doi.org/10.2298/ZMSPN08141 $35 \mathrm{~K}$. 